\title{
Kajian Terbentuknya Scaling pada Komponen Turbin Uap Pembangkit Listrik Tenaga Panas Bumi Skala Kecil
}

\section{Assessment of Scaling Formation on the Steam Turbine Components of Small Scale Geothermal Power Plant}

\author{
AMIRAL AZIZ*, KORNELIS K OLA \\ Balai Besar Teknologi Konversi Energi, Badan Pengkajian dan Penerapan Teknologi \\ Gedung 625 Kluster Energi Puspiptek Serpong Tangerang Selatan \\ Email: amiralaziz58@gmail.com
}

\begin{abstract}
Scaling and corrosion are two major problems in operation of the Small Scale Geothermal Power Plant. This paper discusses some results of the study that was conducted to assess the scaling formation in the Kamojang 3 MW Small Scale Geothermal Power Plant. The result of the study concluded that scaling occurred on the nozzle and steam turbine blade where the main minerals contained in sample $A$ (solid) are Tridymate $\left(\mathrm{SiO}_{2}\right)$, Pyrite $\left(\mathrm{FeS}_{2}\right)$ and Chlorite $\left(\mathrm{ClO}_{2}\right)$. While in sample $B$ (sand) where the main mineral contained in the sample is Tridymate $\left(\mathrm{SiO}_{2}\right)$, Pyrite $\left(\mathrm{FeS}_{2}\right)$, Plagioclase $(\mathrm{Na}, \mathrm{Ca})(\mathrm{Si}, \mathrm{Al}) 4 \mathrm{O}_{8}$ and Chlorite (CIO2). The analysis of this scaling was done by XRD (X-Ray Diffraction) method. Scaling of the nozzle of the steam turbine causes the steam flow rate to decrease, thus lowering the power that the SmallScale Geothermal Power Plant generates because the power generated by the Small-Scale Geothermal Power Plant is directly a function of the steam flow rate and the enthalpy difference between the inlet side and the outlet side of the turbine. However, scaling does not occur on the exit side of the wellhead KMJ 68 because the concentration of silica is very small that is $0.05 \mathrm{ppm}$ at geothermal steam temperature $200.5^{\circ} \mathrm{C}$.
\end{abstract}

Keywords: geothermal steam, scaling, corrosion, Small Scale Geothermal Power Plant

\begin{abstract}
ABSTRAK
Scaling dan korosi merupakan dua masalah yang sangat serius ditemukan pada pengoperasian PLTP Skala Kecil. Tulisan ini membahas sebagian hasil studi yang dilakukan untuk mengkaji pembentukan scaling pada PLTP Skala Kecil Kamojang 3 MW dan pengaruhnya pada daya listrik yang dihasilkan oleh PLTP Skala Kecil. Dari hasil kajian dapat disimpulkan bahwa scaling terjadi pada Nozzle dan sudu-sudu turbin dimana mineral utama yang terdapat didalam sampel A (berupa endapan/padat) adalah Tridymate $\left(\mathrm{SiO}_{2}\right)$, Pyrite $\left(\mathrm{FeS}_{2}\right)$ dan Chlorite $\left(\mathrm{ClO}_{2}\right)$. Sedangkan pada sampel B (endapan lepas/pasiran) dimana mineral utama yang terdapat didalam sampel adalah Tridymate $\left(\mathrm{SiO}_{2}\right)$, Pyrite $\left(\mathrm{FeS}_{2}\right)$, Plagioclase $(\mathrm{Na}, \mathrm{Ca})(\mathrm{Si}, \mathrm{Al}) 4 \mathrm{O}_{8}$ dan Chlorite $\left(\mathrm{ClO}_{2}\right)$. Analisis scaling ini dilakukan dengan menggunakan metoda XRD.(X-Ray Diffraction). Scaling yang terjadi pada bagian nozzle dari turbin uap menyebabkan laju aliran uap berkurang sehingga menurunkan daya yang dihasllkan PLTP Skala Kecil karena daya yang dihasilkan PLTP Skala Kecil secara langsung merupakan fungsi dari laju aliran uap dan perbedaan entalpi antara sisi masuk dan sisi keluar dari turbin. Akan tetapi, tidak terjadi scaling pada sisi keluar kepala sumur KMJ 68 karena kosentrasi silika sangat kecil yaitu sebesar 0,05 ppm pada temperatur uap panas bumi $200,5^{\circ} \mathrm{C}$.
\end{abstract}

Kata kunci : uap panas bumi, scaling, korosi, PLTP Skala Kecil,

\section{PENDAHULUAN}

\subsection{Latar Belakang}

Pembangkit Listrik Tenaga Panas (PLTP) skala kecil berkapasitas 3 MW dibangun BPPT di daerah Kamojang-Garut sejak tahun $2011^{(1)}$ dan saat ini masih menjalani berbagai proses pengujian untuk mendapatkan karakteristik baik sistem maupun masing-masing peralatan yang digunakan.
Pada tahun 2017 dan 2018 kegiatan PLTP Skala Kecil adalah menguji turbin uap dikopel dengan generator sampai dengan putaran operasi $6.450 \mathrm{rpm}$. Pengujian dilakukan dengan rolling turbin uap dari putaran paling rendah 700 rpm, dilakukan selama kurang lebih satu jam sekaligus untuk memanaskan turbin uap agar tercapai temperatur yang merata pada turbin uap (warming up), untuk kemudian di naikan secara bertahap putaran turbin uap dengan menghindari 
titik-titik putaran kritis sesuai dengan hasil bump test. Uji rolling ini dimaksudkan untuk menguji turbin uap beserta seluruh systemnya sampai dengan putaran operasi dan sekaligus masuk jaringan $\mathrm{PLN}^{(2,3)}$.

Dalam pengujian dan pengoperasian PLTP skala kecil nozzle dan blades dari turbin uap merupakan komponen penting dalam pembangkit listrik. Beberapa hasil penelitian telah menunjukkan bahwa nozzle dan blade tekanan rendah dari turbin uap umumnya ditemukan lebih rentan terhadap kegagalan dibandingkan dengan blade tekanan menengah dan tekanan tinggi. Mekanisme kegagalan yang paling umum yang terjadi dalam blade tekanan rendah dewasa ini biasanya yang berhubungan dengan getaran yang disebabkan oleh kondisi operasi, dan yang terjadi sebagai hasil dari ion korosif yang terbawa dan terakumulasi dalam fluida kerja dan diawali oleh pembentukan endapan (scaling) atau deposit pada blade serta komponen peredam atau damping wire.

Lingkungan geothermal memiliki karakteristik khusus yang membedakannya dengan lingkungan yang lain. Karakteristik tersebut adalah kondensat geothermal. Kondesat geothermal merupakan campuran dari air, gas dan unsur-unsur lain yang mengandung sejumlah energi yang cukup untuk menghasilkan daya dengan komposisinya yang unik, Hal ini dikarenakan karakteristiknya yang bersifat korosif dan atau scaling terhadap material.

Scaling didefinisikan sebagai pembentukan endapan atau kerak yang berasal dari mineral garam terlarut dalam air pada suatu media kontak tertentu. Salah satu penyebab terbentuknya scaling adalah adanya kandungan silica (SiO2) yang terkandung dalam brine. Sifatsifat yang mempengaruhi konsentrasi kelarutan silica dalam pembentukan scaling adalah temperatur, kadar garam (salinitas), dan nilai keasaman $(\mathrm{pH})$. Ketika terjadi perubahan tekanan, temperatur, dan $\mathrm{pH}$ pada suatu sistem, keseimbangan ion-ion yang terkandung akan melebihi kelarutannya, sehingga terbentuk suatu endapan.

Penomena scaling dan korosi merupakan dua masalah yang sangat serius ditemukan pada pengoperasian PLTP skala kecil. Hal itu dapat terjadi pada reservoir, pipa produksi, peralatanperalatan pembangkit seperti separator, turbin dsb. Scaling dan korosi sebagai kendala utama pengembangan PLTP di seluruh dunia ${ }^{(15)}$ Oleh sebab itu perlu dilakukan kajian tentang proses terjadinya scaling, pengaruhnya terhadap parameter kinerja PLTP serta langkah-langkah yang harus dilakukan untuk meminimumkan pengaruh terjadinya salling pada PLTP skala kecil.
Tulisan ini menampilkan beberapa hasil studi pembentukan scaling pada sistem PLTP Skala Kecil Kamojang $3 \mathrm{MW}$ dan pengaruhnya pada daya listrik yang dihasilkan oleh PLTP.

\subsection{Tujuan Penelitian}

Studi ini bertujuan untuk mengkaji pembentukan scaling pada sistem PLTP Skala Kecil Kamojang $3 \mathrm{MW}$ dan pengaruhnya pada daya listrik yang dihasilkan oleh PLTP.

\section{BAHAN DAN METODA}

\subsection{Diskripsi PLTP Skala Kecil 3 MW}

Lokasi pembangkit berada di wilayah sekitar pengembangan sumur $\mathrm{KMJ}-68$ dengan jarak dari sumur KMJ-68 ke pembangkit adalah sekitar 50 meter menuju arah barat daya, koordinat pembangkit secara geografis terletak pada $158^{\circ}$ 43' 60" BT. Gambar 1 memperlihatkan situasi sumur Kamojang dan sumur reinjeksi. Air kondensat yang akan diinjeksikan adalah kurang lebih $20 \%$ dari jumlah uap yang masuk ke turbin dimana air ini disalurkan ke sumur KMJ-21 yang berlokasi kurang lebih $1.3 \mathrm{~km}$ sebelah barat laut dari pembangkit.

Fluida dari sumur KMJ 68 dialirkan kedalam separator dimana sebelumnya tekanan diturunkan dari tekanan pada kepala sumur 12 bar menjadi 6,5 bar di separator dengan menggunakan pressure regulator valve. Pada separator uap dan air dipisahkan, uap panas bumi kemudian sebagian besar diekspansikan melalui turbin dan sebagian dialirkan ke steam ejector dan gland condenser.

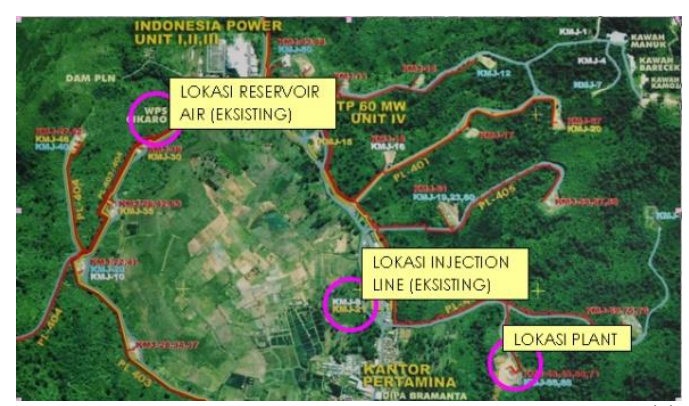

Gambar.1. Gambar situasi sumur Kamojang(1)

Setelah diekspansi di dalam turbin, uap dikondensasi oleh air pendingin di dalam kondensor, sementara NCG (Non Condensing Gas) tetap dalam kondisi gas.

PLTP dengan sistem kondensing terdiri dari sub-sistem berupa kelompok peralatan yang secara garis besar dapat dikelompokkan sebagai berikut ${ }^{(2,3)}$ :

a. Turbine island yang terdiri dari turbin uap, generator, governor dan peralatan pendukungnya seperti sistem pelumasan dan pendinginan baik untuk turbin dan 
generator maupun sistem hidrolik untuk menggerakkan governor.

b. Peralatan mekanikal rotating (rotating equipment) non-turbin yang terdiri dari pompa-pompa seperti hot well pump, auxiliary pump, liquid ring vacuum pump dan pompa atau kompresor lain yang menjadi bagian dari sistem pendukung seperti sistem gas bertekanan dan sistem pemadam kebakaran.

c. Peralatan mekanikal stasioner yang terdiri dari separator/demister, kondensor utama, steam jet ejector, kondensor untuk steam jet ejector, dan cooling tower.

d. Sistem pendukung seperti sistem udara bertekanan, sistem pemadam kebakaran, sistem re-injeksi air dan air penambah, dll.

e. Sistem instrumentasi dan kontrol yang terdiri dari berbagai alat ukur, perangkat keras dan perangkat lunak pengendalian sistem untuk integrasi sistem pembangkit.

f. Sistem elektrikal yang meyediakan daya listrik untuk peralatan dan gedung, mengendalikan dan mentransmisikan listrik yang dihasilkan, mengatur sistem daya cadangan jika terjadi kehilangan daya listrik ke PLTP.

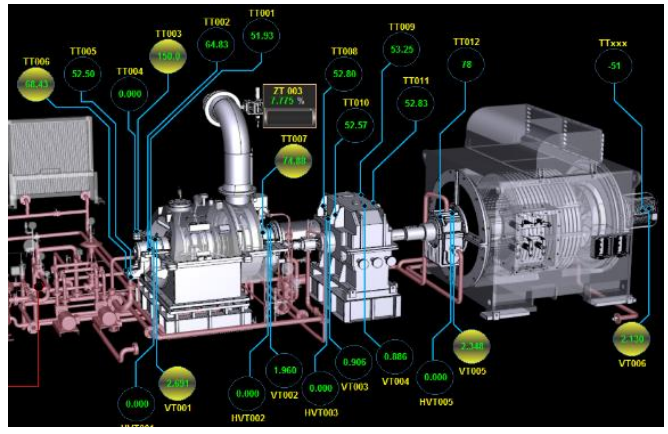

Gambar 2. Sistem turbin generator PLTP Skala Kecil 3 MW $^{(2,3)}$.

Gambar 2 memperlihatkan Sistem Turbine Generator PLTU Panas Bumi 3 MW. Konstruksi turbin uap PLTU Panas Bumi 3 MW berupa solid shaft dan drum (tanpa disk), dengan susunan sudu, dimana pada susunan blade terakhir akan ditahan dengan blade locking yang dikunci menggunakan "pen".

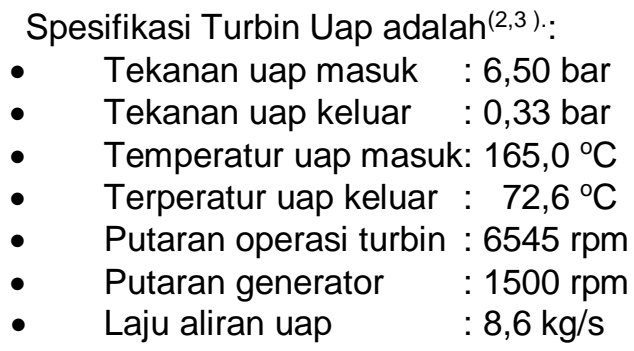

\subsection{Metodologi}

Terdapat dua titik pengambilan sampel seperti diperlihatkan pada Gambar 4. Untuk mendapat data karakteritik fluida panas bumi dari sumur KMJ 68 sampel fluida diambil pada titik setelah kepala sumur, sedangkan untuk menganalisis karakteristik endapan/scaling yang terbentuk didaerah turbin sampel diambil pada daerah blade turbin. Sampel fluida dan endapan dianalisis di laboratorium milik PGN Petamina Kamojang. Metoda yang dipakai untuk mengetahui karakteristik endapan pada daerah turbin digunakan analisis XRD( $X$-Ray Diffraction).

Difraksi sinar-X adalah alat untuk menyelidiki struktur dari suatu material.Teknik ini berawal dalam penemuan Von Laue pada tahun 1912 tentang difraksi sinar-X kristal, cara difraksi untuk menunjukkan struktur kristal. Pada awalnya, difraksi sinar- $X$ hanya digunakan untuk penentuan struktur kristal. Kemudian, kegunaan lain dikembangkan, dan sekarang metode ini diterapkan tidak hanya untuk penentuan struktur, tapi untuk masalah beragam seperti analisis kimia dan pengukuran tekanan, untuk mempelajari kesetimbangan fasa dan pengukuran ukuran partikel, untuk penentuan orientasi Kristal tunggal atau ensambel dari orientasi dalam agregat polikristalin(7).

Terbentuknya suatu pola difraksi konstruktif hanya bisa terjadi apabila dua gelombang atau lebih mempunyai hubungan fasa tertentu. Jadi difraksi sinar-X yang akan ditinjau adalah berasal dari susunan atom-atom yang tersusun teratur secara periodik sesuai posisi tertentu di dalam kristal. Sehingga atom di dalam kristal dapat dipandang berada pada bidang yang sejajar satu sama lain yang dipisahkan oleh jarak $d$, seperti ditunjukkan oleh Gambar 3.

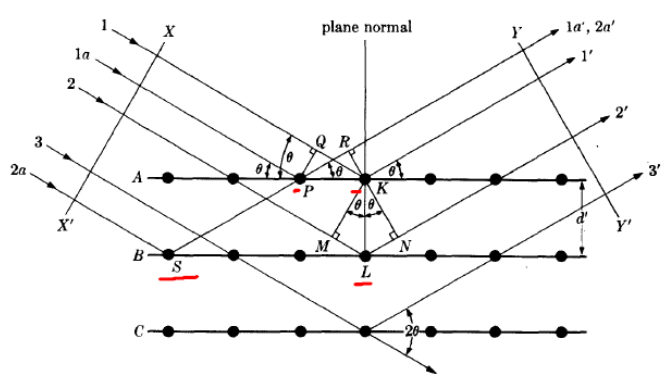

Gambar 3. Prinsip kerja metoda XRD

Berdasarkan Gambar 3, diasumsikan bahwa berkas sinar-X yang datang pada bahan sejajar satu sama lain, mempunyai hanya satu panjang gelombang $(\lambda)$ dan dengan sudut datang dinyatakan dengan $\theta$ terhadap bidang difraksi (sudut Bragg). Besar sudut Bragg ini tentunya akan mempunyai harga berbeda untuk tiap-tiap bidang 
Sehingga persamaan:

$n \times \lambda=2 \times d \times \sin \theta$

terpenuhi, dan persamaan ini dikenal dengan Hukum Bragg. dan sudut $\theta$ dikenal sebagai sudut Bragg untuk penyinaran sinar-X oleh bidangbidang atom hablur yang dipisahkan pada jarak d. dan $n=1,2,3,$. . Prinsip inilah yang kemudian digunakan dalam mesin XRD atau $X$ Ray Difractometer

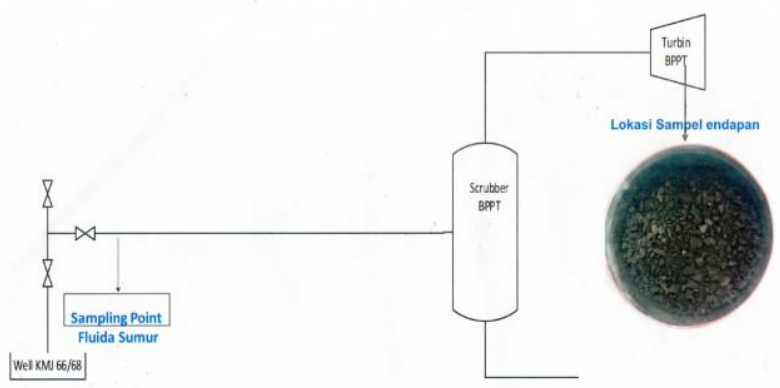

Gambar 4. Titik pengambilan sampel fluida dan endapan (Scaling)

\section{HASIL DAN PEMBAHASAN}

Pada Tabel 1 dan Tabel 2 dapat dilihat hasil analisis komposisi kimia fluida (uap) panas bumi sumur KMJ 68 dan analisis sampel gas NCG KMJ 68 Fluida KMJ 68 mengandung diantaranya 22,1 ppm Hydrogen Sulfida $\left(\mathrm{H}_{2} \mathrm{~S}\right), 15,176$ ppm Bicarbonat $\left(\mathrm{HCO}_{3}\right), 3,547 \mathrm{ppm} \mathrm{Ammonium}\left(\mathrm{NH}_{3}\right)$, 0,962 ppm Baron (B) dan 0,05 Silica $\left(\mathrm{SO}_{2}\right)$. Dari analisis gas NCG, terdapat kandungan $\mathrm{H}_{2} \mathrm{~S}$ sebesar 2,82 $\mathrm{mmol} / \mathrm{kg}$ condensat dan kandungan $\mathrm{CO}_{2}$ sebesar $147,62 \mathrm{mmol} / \mathrm{kg}$ condensat.

Tabel.1. Analisis sampel fluida sumur KMJ 68

\begin{tabular}{clcc}
\hline No & \multicolumn{1}{c}{ Parameter } & Satuan & Nilai \\
\hline $\mathbf{1}$ & $\begin{array}{l}\text { Waktu } \\
\text { pengambilan }\end{array}$ & menit & 20 \\
\hline $\mathbf{2}$ & $\begin{array}{l}\text { Electrical } \\
\text { Conductivity }\end{array}$ & Mic/cm & 11,8 \\
\hline $\mathbf{3}$ & $\mathrm{pH} /$ temp $25^{\circ} \mathrm{C}$ & - & 4,659 \\
\hline $\mathbf{4}$ & $\begin{array}{l}\text { TDS by } \\
\text { calculation }\end{array}$ & $\mathrm{ppm}$ & 1,174 \\
\hline $\mathbf{5}$ & Natrium (Na) & $\mathrm{ppm}$ & $<0,200$ \\
\hline $\mathbf{6}$ & Kalium (K) & $\mathrm{ppm}$ & $<0,200$ \\
\hline $\mathbf{7}$ & Calcium (Ca) & $\mathrm{ppm}$ & $<0,200$ \\
\hline $\mathbf{8}$ & Magnesium (Mg) & $\mathrm{ppm}$ & $<0,100$ \\
\hline $\mathbf{9}$ & Lithium (Li) & $\mathrm{ppm}$ & $<0,500$ \\
\hline $\mathbf{1 0}$ & $\begin{array}{l}\text { Ammonimum } \\
\left.\text { (NH })_{3}\right)\end{array}$ & $\mathrm{ppm}$ & 3,547 \\
\hline $\mathbf{1 1}$ & Besi (Fe) & $\mathrm{ppm}$ & 0,003 \\
\hline $\mathbf{1 2}$ & $\begin{array}{l}\text { Bicarbonat } \\
\text { (HCO })\end{array}$ & $\mathrm{ppm}$ & 15,716 \\
\hline $\mathbf{1 3}$ & Clorida (Cl) & $\mathrm{ppm}$ & $<0,100$ \\
\hline $\mathbf{1 4}$ & Sulphat (SO4) & $\mathrm{ppm}$ & 0,305 \\
\hline $\mathbf{1 5}$ & $\begin{array}{l}\text { Hydrogen Sulfide } \\
\text { (H2s) }\end{array}$ & $\mathrm{ppm}$ & 22,1 \\
\hline
\end{tabular}

\begin{tabular}{clcc}
\hline No & Parameter & Satuan & Nilai \\
\hline $\mathbf{1 6}$ & Baron $(\mathrm{B})$ & $\mathrm{ppm}$ & 0,962 \\
\hline $\mathbf{1 7}$ & Silika $\left(\mathrm{SiO}_{2}\right)$ & $\mathrm{ppm}$ & 0,05 \\
\hline
\end{tabular}

Tabel.2. Analisis sampel gas (NCG) KMJ 68

\begin{tabular}{|c|c|c|c|}
\hline No & Parameter & Satuan & Nilai \\
\hline 1 & $\begin{array}{l}\text { Waktu } \\
\text { pengambilan }\end{array}$ & menit & 20 \\
\hline 2 & $\mathrm{CO}_{2}$ & $\begin{array}{l}\mathrm{mmol} / 100 \mathrm{~mol} \\
\text { cond }\end{array}$ & 292,35 \\
\hline 3 & $\mathrm{H}_{2} \mathrm{~S}$ & $\begin{array}{l}\mathrm{mmol} / 100 \mathrm{~mol} \\
\mathrm{cond} \text { - }\end{array}$ & 8,41 \\
\hline 4 & $\mathrm{CO}_{2}$ & $\mathrm{mmol} / \mathrm{kg}$ cond & 162,41 \\
\hline 5 & $\mathrm{H}_{2} \mathrm{~S}$ & $\mathrm{mmol} / \mathrm{kg}$ cond & 4,67 \\
\hline 6 & Gas Sisa & $\begin{array}{c}\mathrm{mmol} / 100 \mathrm{~mol} \\
\mathrm{cond}\end{array}$ & 6,18 \\
\hline 7 & $\begin{array}{l}\text { Mol Ratio } \\
\mathrm{CO}_{2} / \mathrm{H}_{2} \mathrm{~S}\end{array}$ & & 34,76 \\
\hline 8 & PCT Volume & $\%$ & 0,31 \\
\hline 9 & PCT Berat & $\%$ & 0,74 \\
\hline 10 & TKS & $\mathrm{Kg} / \mathrm{cm}^{2}$ & 17 \\
\hline 11 & Temperatur & ${ }^{\circ} \mathrm{C}$ & 201,4 \\
\hline
\end{tabular}

Gambar 5, 6, 7, dan 8 memperlihatkan terjadinya endapan (scaling) pada saluran uap (steam piping) dan turbin uap. Kandungan $\mathrm{H}_{2} \mathrm{~S}$ yang tinggi secara umum menimbulkan masalah metalurgi seperti korosi tegangan (stress corrotion), retak (cracking) dan kelelahan metal (metal fatique).

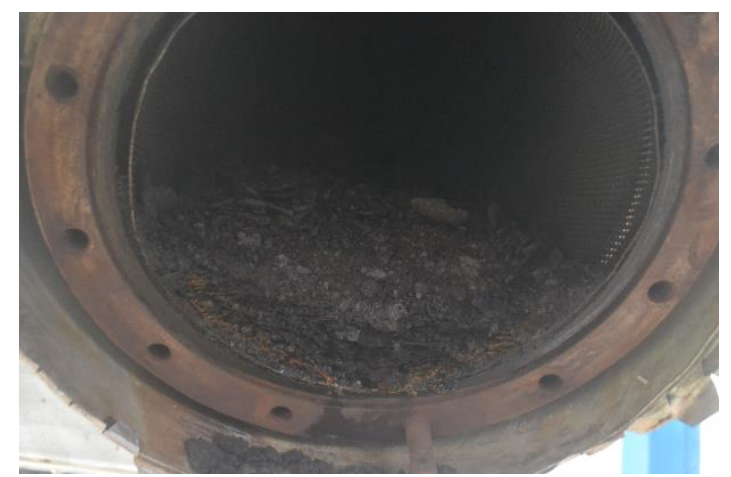

Gambar 5. Endapan (Scaling) yang terjadi pada pipa uap PLTP Skala Kecil

Pada Gambar 6 dapat dilihat terjadinya korosi pada bagian pipa dari uap panas bumi. PLTP Kamojang $3 \mathrm{MW}$ yang beroperasi dengan temperatur uap panas bumi pada sisi masuk turbin adalah $165^{\circ} \mathrm{C}$, sedangkan kandungan $\mathrm{CO}_{2}$ yang tinggi pada temperatur uap panas bumi dibawah $200^{\circ} \mathrm{C}$ akan mempercepat terbentuknya calcite scaling dan korosi aktif (active corrotion) $)^{(5)}$. 


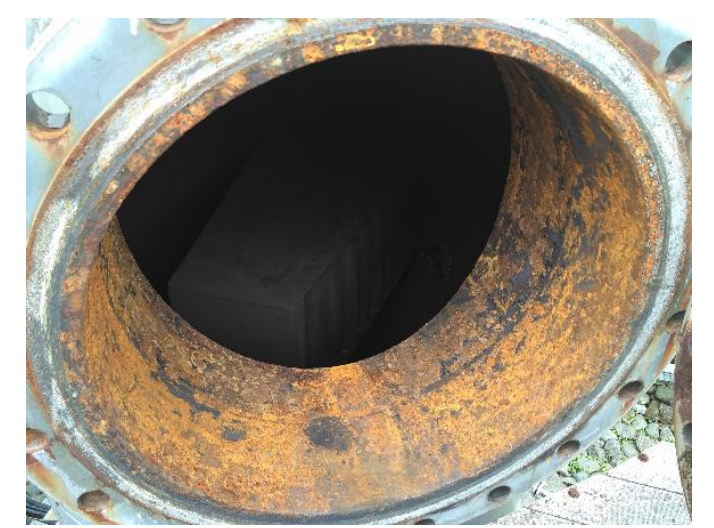

Gambar 6. Endapan (Scaling) dan korosi yang terjadi pada pipa uap PLTP Skala Kecil

Laju aliran korosi pada sebagian besar material akan meningkat apabila terjadi penurunan $\mathrm{pH}$ dari fluida panas bumi. Fluida panas bumi bertemperatur rendah mempunyai $\mathrm{pH}$ yang tinggi yaitu 8-10 sedangkan fluida panas bumi bertemperatur tinggi mempunyai $\mathrm{pH}$ 6-8, akan tetapi $\mathrm{pH}$ air yang ekstrim adalah 2 paling rendah dan 12 paling tinggi(9). Pada Tabel 1 dapat dilihat bahwa $\mathrm{pH}$ fluida panas bumi Kamojang 68 adalah 4,659, $\mathrm{pH}$ yang rendah dapat menyebabkan terjadinya korosi pada pipa baja karbon dan dapat menyebabkan retak korosi pada pipa baja tahan karat ${ }^{(9)}$.

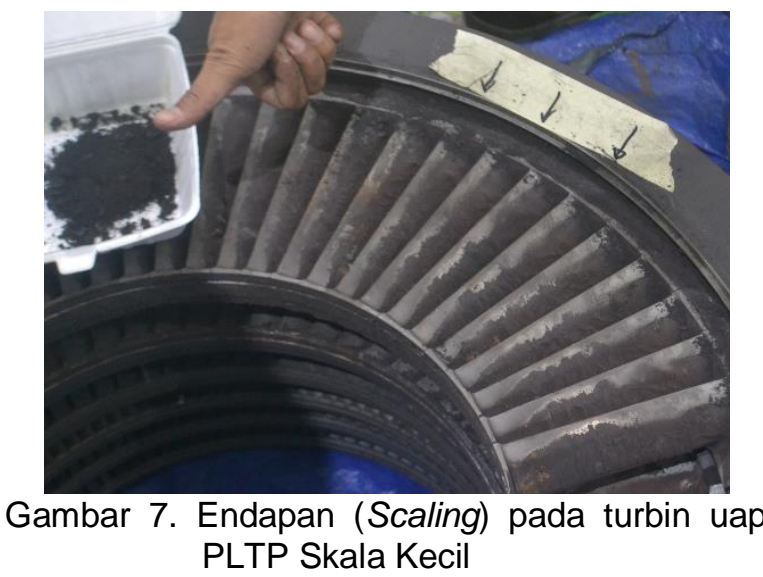

Berdasarkan Tabel 1 dapat dilihat bahwa kandungan silika $\left(\mathrm{SiO}_{2}\right)$ dalam uap panas bumi KMJ 68 adalah 0,05 ppm. Berdasarkan Gambar 9 dapat dilihat bahwa dengan menggunakan kurva Kosentrasi (Solubilitas) Silika di dalam air, pada titik 1 dimana kandungan $\mathrm{SiO}_{2}$ sebesar 0,05 ppm dan temperatur $200,5^{\circ} \mathrm{C}$, tidak terjadi Silica Scaling pada titik pada saluran uap di keluar kepala sumur. Untuk temperatur $200,5^{\circ} \mathrm{C}$ scaling akan terjadi pada titik 2 apabila kandungan Silika sekitar 1000 ppm. Dengan demikian dapat dinyatakan bahwa dengan berdasarkan kosentrasi Silika yang sangat kecil pada kondisi fluida superheated tidak memungkinkan terjadinya scaling disisi kepala sumur KMJ 68. Dengan menjaga temperatur uap panas bumi diatas level kosentrasi dari amorphous silica, laju aliran scaling sangat rendah, oleh karena itu parameter ini adalah salah satu kriteria desain untuk merancang sebuah PLTP(16).

Tejadi scaling pada komponen turbin seperti dapat dilihat pada Gambar 7 dan Gambar 8. Ada dua macam endapan yang dianalisis yaitu sampel endapan pada turbin (sampel A) berupa butiran padat (Gambar 10) dan endapan pada turbin (sampel B) berupa material lepas pasiran (Gambar 11). Gambar 12 dan 13 memperlihatkan hasil analisis sampel endapan (scaling) pada komponen turbin dengan menggunakan metoda analisis XRD.(X-Ray Diffraction).

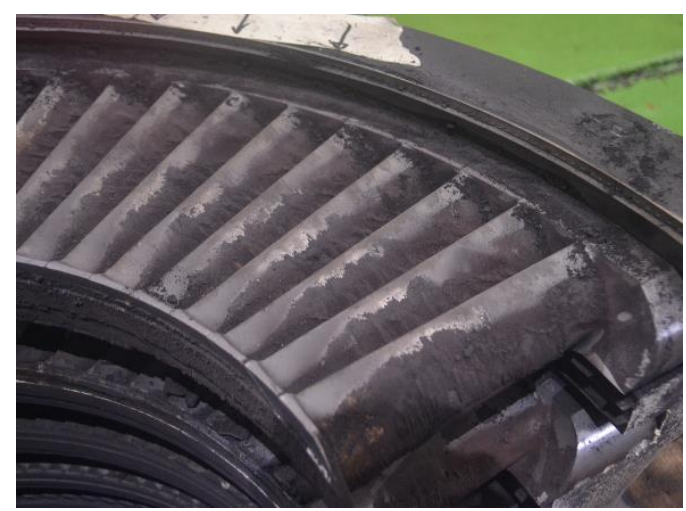

Gambar 8. Endapan (Scaling) pada turbin uap PLTP Skala Kecil

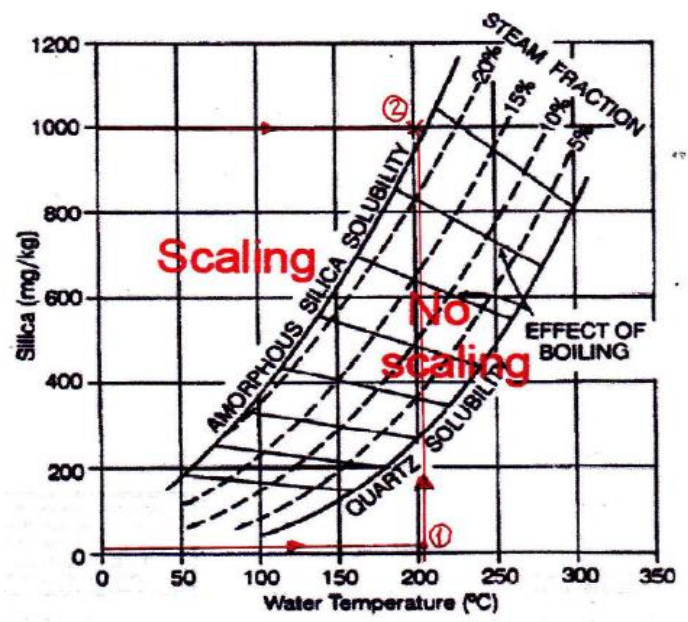

Gambar 9. Kosentrasi silika didalam air ${ }^{(16)}$

Pada Gambar 12 dapat dilihat kandungan senyawa/mineral pada endapan/padatan A dimana mineral utama yang terdapat didalam sampel adalah Tridymate $\left(\mathrm{SiO}_{2}\right)$, Pyrite $\left(\mathrm{FeS}_{2}\right)$ dan Chlorite $\left(\mathrm{ClO}_{2}\right)$. Sedangkat pada gambar 12 dapat dilihat kandungan senyawa/mineral pada endapan lepas/pasiran B dimana mineral utama yang terdapat didalam sampel adalah Tridymate 
$\left(\mathrm{SiO}_{2}\right)$, Pyrite $\left(\mathrm{FeS}_{2}\right)$, Plagioclase $(\mathrm{Na}$, $\mathrm{Ca})(\mathrm{Si}, \mathrm{Al}) 4 \mathrm{O}_{8}$ dan Chlorite $\left(\mathrm{ClO}_{2}\right)$.

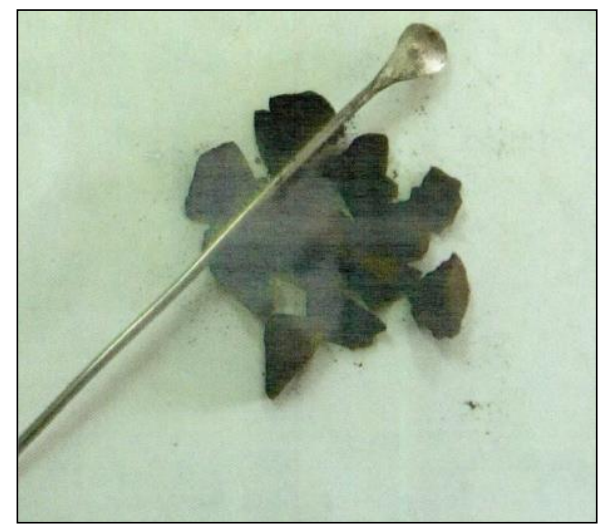

Gambar 10. Sampel A berupa butiran padat

Sebagian besar kerusakan (damage) pada komponen turbin (nozzle dan blade) biasanya berhubungan dengan karakteristik uap panas bumi. Apabila uap panas bumi bersih dan biasanya hanya terjadi erosi yang lambat (slow erosive wear). Permasalahan utama adalah terjadinya scaling pada daerah antara dimana terjadinya perbedaan tekanan yang tidak efektif karena adanya misalignment, distorsi atau ruang sisa yang berlebihan (excessive clearances).

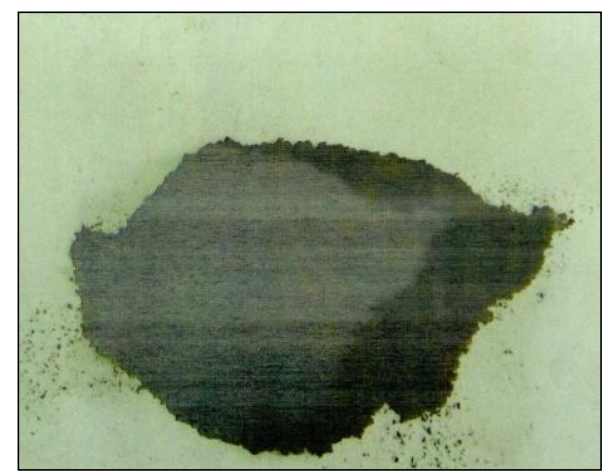

Gambar 11. Sampel B berupa pasiran
Daya mekanik yang dihasilkan turbin uap dari PLTP Skala Kecil adalah perkalian laju aliran massa uap panas bumi dan perbedaan entalpi uap panas bumi antara sisi masuk turbin dan sisi keluar turbin. Sehingga daya listrik kotor yang dihasilkan generator PLTP Skala Kecil adalah ${ }^{(4,}$ 8):

$$
P_{\text {gross }}=m_{s} \times\left(h_{i}-h_{o}\right) \times \eta_{m} \times \eta_{g}
$$

Dimana:

$P_{\text {gross }}=$ daya kotor yang dihasilkan generator $(\mathrm{kW})$

$\mathrm{m}_{\mathrm{s}}=$ laju aliran uap panas bumi $(\mathrm{kg} / \mathrm{s})$

$h_{i}=$ entalpi uap panas bumi pada sisi masuk turbin uap $(\mathrm{kJ} / \mathrm{kg})$.

$h_{o}=$ entalpi uap panas bumi pada sisi keluao turbin uap $(\mathrm{kJ} / \mathrm{kg})$.

$\eta_{\mathrm{m}}=$ efisiensi mekanis

$\eta_{\mathrm{m}}=$ efisiensi generator

Berdasarkan Persamaan 2 diatas jelas bahwa laju aliran uap merupakan salah satu parameter besarnya daya yang dihasilkan PLTP Skala Kecil. Disposisi silika scaling pada sebagian besar terjadi pada bahagian nozzle turbin uap dan hanya sedikit terjadi pada blade tingkat pertama dari turbin. Scaling menyebabkan laju aliran uap berkurang sehingga menurunkan daya yang dihasllkan PLTP Skala Kecil karena daya yang dihasilkan PLTP Skala Kecil secara langsung merupakan fungsi dari laju aliran uap dan perbedaan entalpi antara sisi masuk dan sisi keluar dari turbin seperti dinyatakan oleh Persamaan 2 diatas.

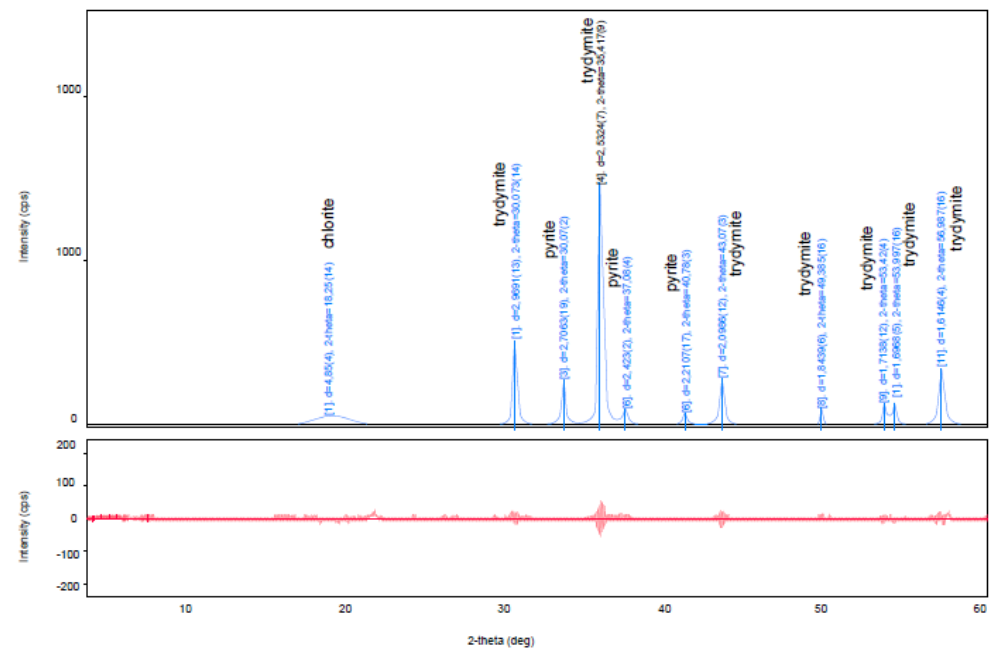

Gambar 12. Grafik kandungan senyawa mineral pada endapan padat (Sampel A) 

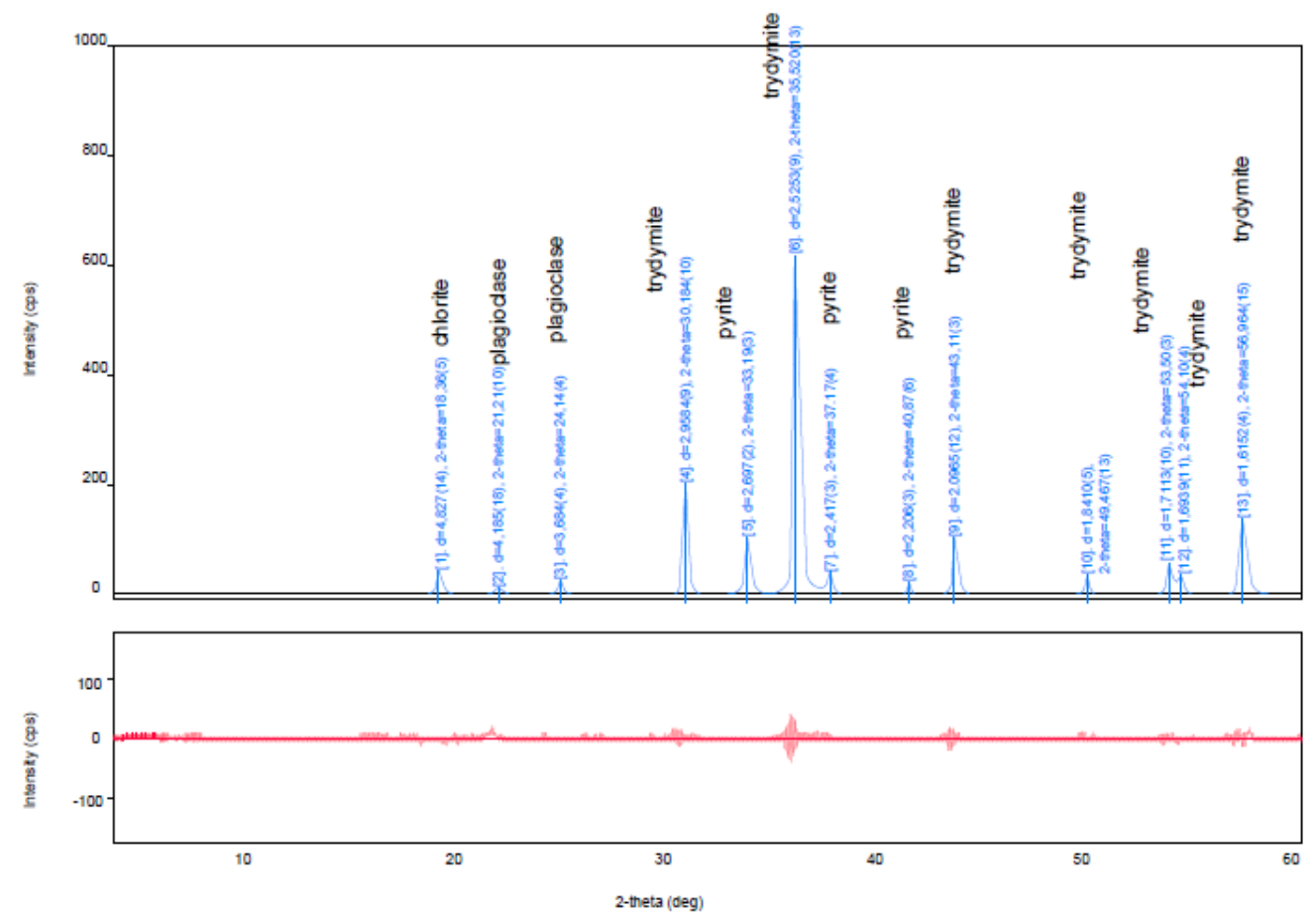

Gambar 13. Grafik kandungan senyawa mineral pada endapanLepas/ pasiran (Sampel B)

\section{KESIMPULAN}

Berdasarkan hasil kajian diatas dapat simpulkan sebagai berikut :

- Bedasarkan analisis menggunakan XRD (X-Ray Diffraction), tejadi scaling pada sisi turbin dimana mineral utama yang terdapat didalam sampel A (berupa endapan/padat) adalah Tridymate $\left(\mathrm{SiO}_{2}\right)$, Pyrite $\left(\mathrm{FeS}_{2}\right)$ dan Chlorite $\left(\mathrm{ClO}_{2}\right)$. Sedangkan pada sampel $\mathrm{B}$ (endapan lepas/pasiran) dimana mineral utama yang terdapat didalam sampel adalah Tridymate $\left(\mathrm{SiO}_{2}\right)$, Pyrite $\left(\mathrm{FeS}_{2}\right)$, Plagioclase $(\mathrm{Na}, \mathrm{Ca})(\mathrm{Si}, \mathrm{Al}) 4 \mathrm{O}_{8} \quad$ dan Chlorite $\left(\mathrm{ClO}_{2}\right)$.

- Scaling yang terjadi pada bagian nozzle dari turbin uap menyebabkan laju aliran uap berkurang sehingga menurunkan daya yang dihasllkan PLTP Skala Kecil karena daya yang dihasilkan PLTP Skala Kecil secara langsung merupakan fungsi dari laju aliran uap dan perbedaan entalpi antara sisi masuk dan sisi keluar dari turbin.

- Tidak terjadi scaling pada sisi keluar kepala sumur KMJ 68 karena kosentrasi Silika sangat kecil yaitu sebesar $0,05 \mathrm{ppm}$ pada temperatur uap pans bumi $200,5^{\circ} \mathrm{C}$.

\section{DAFTAR PUSTAKA}

1. Amiral, A. (2011). Analisis Eksergi PLTP Kamojang 68 Kapasitas $3 \mathrm{MW}$, Jurnal
Rekayasa Lingkungan, Vol No 2115-125, Pusat Teknologi Lingkungan - BPPT.

2. Amiral, A. (2016). Technical Documen Laporan Supervisi Pengujian Peralatan Mekanikal PLTP 3 MW - PB 300, Program Pengembangan PLTP Skala Kecil, Balai Besar Teknologi Konversi Energi - BPPT.

3. Amiral, A. (2017). Technical Documen Laporan Supervisi Pengujian Peralatan Mekanikal PLTP 3 MW - PB 300, Program Pengembangan PLTP Skala Kecil, Balai Besar Teknologi Konversi Energi - BPPT.

4. Black and Veath, Lawrance F. Drbal, Patricia G. B., Kayla L W. \& R. Bruce E. (1996). Power Plant Engineering, Chapman \& Hall, New York, p 38-95.

5. Buzianu, A. (2016). Some Analysis of Major Impact of Geothermal Fluid Components in Power Plant Equipment, International Conference in Innovative Research 2016 IOP Conference Series - Material Science and Engineering.

6. Chris, M. \& Alan, R. (2015). Geothermal Turbines - A Maintainer's Perspective, Proceeding World Geothermal Congress 2015, Melbourne, Australia.

7. Cullity, B. D. (1978). Element of X-Ray Diffraction Second Edition. Addition-Wesley Publishing Company, Inc. Philippines. p. III, 3, 82-84. 
8. El Wakil, M. M. (1984). Power Plant Tecnology, Mc Graw - Hill Book Company, New York, p 499-529.

9. Gunnlaugsson E, Halldór, Á., Sverrir T. \& Benedikt, S. (2014). Problems in Geothermal Operation Scaling and Corrosion, United Nation University Geothermal Training Programme, El Salvador.

10. Gurnarson, I. \& Arnórson, S. (2003), Silica scaling: The main obstacle in efficient use of high-temperature geothermal fluids. International Geothermal Conference, Reikjavick, S13 Paper 118, pp 30-36.

11. Grassiani, M. (2005). Stailess Steel Corrosion in Geothermal Condensing Steam. Stainless Steel, Conference, Maastrich, the Netherlands.

12. Muhammad, A. K. (2005). Assessment of Scaling Formation in Steam Pipeline of Production Well KMJ 67 in Kamojang Geothermal Field West Java - Indonesia, Report No 10, Geothermal Training Programme, The United Nation University, Reykjavík, Iceland.
13. Ocampo, J., Quintero, M., \& Moya, A. (2005). The silica scaling as a predominant factor of the production in Cerro Prieto geothermal wells. Proceedings World Geothermal Congress, Antalya, Turkey.

14. Otakar, J. \& Lee, M. (2008), Steam Turbine Corrosion and Deposit Problem and Solution, Proceeding of the Thirty Seventh Turbo Machinary Symposium,

15. Stapleton, M. (2008). Scaling and Corrosion in Geothermal Operation, PowerChem Technology.

16. Sverrir, T. (2006). Common Problems Faced in Geothermal Generation and How to deal with them Presented at Workshop for Decision Makers on Geothermal Projects in Central America, organized by UNU-GTP and LaGeo in San Salvador, El Salvador.

17. Vetter, O.J \& Kandarpa, V. (1982), Handling of Scale in Geothermal Operation, International Conference on Geothermal Energy, Florence, Paper E2 